\title{
EKSPRESI $\beta 4$ INTEGRIN DAN COX-2 PADA OSTEOSARKOMA STADIUM ENNEKING IIB DAN IIIB
}

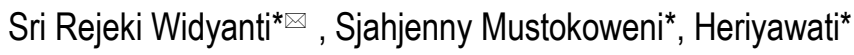

\begin{abstract}
Abstrak
Osteosarkoma adalah keganasan primer pada tulang yang paling sering ditemukan, memiliki distribusi usia bersifat bimodal dengan kecenderungan metastasis yang tinggi dan di RSUD Dr.Soetomo paling banyak ditemukan pada stadium Enneking IIB dan IIIB. Hal ini menunjukkan pentingnya faktor prognosis dalam meningkatkan angka ketahanan hidup penderita. $\beta 4$ integrin dan COX-2 terkait dalam menilai prognosis suatu osteosarkoma. Penelitian ini bertujuan untuk membuktikan ekspresi $\beta 4$ integrin dan COX-2 sebagai marker prognostik pada osteosarkoma stadium Enneking IIB dan IIIB. Desain penelitian adalah analitik observasional dengan pendekatan cross sectional. Sampel penelitian dengan total sampling didapatkan 39 blok parafin penderita osteosarkoma stadium Enneking IIB dan IIIB di RSUD Dr. Soetomo Surabaya periode 1 Januari 2013 hingga 31 Desember 2017. Ekspresi $\beta 4$ integrin dan COX-2 dideteksi dengan pewarnaan imununohistokimia menggunakan antibodi monoklonal $\beta 4$ integrin dan COX-2, evaluasi ekspresi berdasarkan nilai scoring semikuantitatif. Perbedaan ekspresi $\beta 4$ integrin dan COX-2 dianalisis secara statistik dengan Mann Whitney dan hubungannya dianalisis menggunakan uji Spearman. Hasil penelitian menunjukkan tidak didapatkan perbedaan ekspresi $\beta 4$ integrin dan COX-2 terhadap osteosarkoma stadium Enneking IIB dan IIIB $(p>0,05)$. Tidak didapatkan hubungan ekspresi $\beta 4$ integrin dan COX-2 terhadap osteosarkoma stadium Enneking IIB dan IIIB $(p>0,05)$. Didapatkan hubungan bermakna antara ekspresi $\beta 4$ integrin dan COX-2 $(p=0,008$ dan $r=0,41)$. Kesimpulan penelitian ini adalah tidak didapatkan perbedaan dan hubungan antara ekspresi $\beta 4$ integrin serta COX-2 terhadap stadium Enneking IIB dan IIIB, sehingga kedua protein tersebut tidak dapat digunakan sebagai marker prognostik.
\end{abstract}

Kata kunci: $\beta 4$ integrin, COX-2, osteosarkoma, stadium Enneking.

\section{THE EXPRESSION OF $\beta 4$ INTEGRIN AND COX-2 ON ENNEKING STAGE IIB AND IIIB OF OSTEOSARCOMA}

\section{Abstrak}

Osteosarcoma is the most common malignancy of the bone, with bimodal distribution in age and high metastatic tendency. It is most commonly found in Enneking IIIB and IIIB stages in Dr. Soetomo hospital. This suggests an important role of prognostic factors to improve survival rates. Expression of $\beta 4$ integrins and COX-2 are related to the prognosis assessment of an osteosarcoma. Aim of this study was to prove the expression of $\beta 4$ integrin and COX-2 as prognostic marker on Enneking stage IIB and IIIB of osteosarcoma. Method of this study is analytical observational with cross sectional. Total sampling was conducted on 39 paraffin blocks of patients with IIB and IIIB Enneking stage at Dr. Soetomo hospital Surabaya during 1 January 2013 to 31 December 2017. Expression of $\beta 4$ integrin and COX-2 were tested by immununohistochemical staining with $\beta 4$ integrin and COX-2 monoclonal antibodies, their expression was evaluated by semi-quantitative scoring. Differences in expression of $\beta 4$ integrin and COX-2 were analyzed with Mann Whitney statistical test, while correlation was analyzed with Spearman test. The results showed no differences in the expression of $\beta 4$ integrin and COX-2 on IIB and IIIB Enneking stage of osteosarcoma ( $p$ $>0.05$ ). There were no correlation between expression of $\beta 4$ integrin and COX-2 on IIB and IIIB Enneking stage of osteosarcoma $(p>0.05)$. A significant correlation was found between expression of $\beta 4$ integrin and $\operatorname{COX}-2(p=0.008, r=0.41)$. To conclude, there were no difference and correlation between $\beta 4$ integrin and COX-2 exspression with III and IIIB Enneking stage of osteosarcoma, so that the two proteins could not be used as prognostic markers.

Keywords: $\beta 4$ Integrin, COX-2, Enneking stage, osteosarcoma.

*Departmen Patologi Anatomy, Fakultas Kedokteran, Universitas Airlangga

E-mail: wiwied_79@yahoo.co.id dan smustokoweni@gmail.com 


\section{Latar Belakang}

Osteosarkoma adalah tumor ganas tulang primer yang berasal dari sel mesenkimal primitif yang memproduksi tulang dan matriks osteoid serta kelainan nonhemopoetik tulang primer yang paling sering ditemukan. Insiden osteosarkoma pada semua populasi menurut WHO sekitar 4-5 per 1.000 .000 penduduk. ${ }^{1} \quad$ Osteosarkoma mempunyai distribusi usia bimodal yaitu pada usia muda, terbanyak usia 10-14 tahun dan puncak kedua pada usia dewasa tua $30 \%$ terjadi pada usia lebih dari 40 tahun). Lebih sering terjadi pada laki-laki daripada wanita dengan perbandingan $2: 1 .^{2}$

Stadium dalam osteosarkoma yang dikenal saat ini adalah sistem Enneking yang pertama kali digunakan oleh American Musculoskeletal Tumor Society dan International Symposium on Limb-Salvage. Sistem lain adalah American Joint Committee on Cancer (AJCC). Di Rumah Sakit Dr. Soetomo lebih lazim menggunakan sistem Enneking. Secara garis besar pada sistem ini kategori morfologi sel terbagi menjadi derajat tinggi/high grade dan derajat rendah/low grade bergantung pada selularitas, pleomorfisme, anaplasia, jumlah mitosis dan adanya metastasis serta perluasan atau invasi tumor keluar kompartemen. ${ }^{3}$ Stadium yang semakin meningkat menunjukkan aktifitas dan perilaku sel tumor yang agresif dan progresif serta cenderung untuk metastasis.

Beta empat integrin ( $\beta 4$ integrin) merupakan laminin reseptor lazim terekspresi pada lapisan basal sel jaringan. $\beta 4$ integrin mempunyai keunikan pada ekor sitoplasma yang panjang berinteraksi dengan jaringan filamen intermediat sehingga berfungsi mempertahankan integritas jaringan normal terhadap stres. Secara struktural $\beta 4$ Integrin berpasangan dengan subtipe a6 integrin. Integrin sendiri adalah keluarga dari protein transmembran yang terekspresi hampir di setiap tipe sel berperan sebagai media perlekatan dengan extracellular matrix (ECM), mengatur fungsi fisiologi termasuk migrasi dan proliferasi sel. ${ }^{4}$ Peningkatan ekspresi $\beta 4$ integrin terjadi pada osteosarkoma derajat tinggi dan terekspresi pada sel tumor yang bermetastasis, sehingga semakin tinggi stadium Enneking pada Osteosarkoma maka ekspresi $\beta 4$ Integrin semakin meningkat. ${ }^{5}$

Cyclooxygenase 2 (COX-2) adalah enzim katalisis yang merangsang sintesis prostanoid termasuk prostaglandin E2 (PGE2). COX-2 terekspresi pada sel-sel kanker dan berhubungan dengan progresifitas pertumbuhan tumor. Peningkatan ekspresi COX-2 menunjukkan peningkatan proliferasi sel, migrasi, angiogenesis, metastasis, hambatan apoptosis dan imunosupresi sehingga semakin tinggi stadium Enneking Osteosarkoma maka ekspresi COX-2 semakin meningkat. ${ }^{6}$

Teknologi imunohistokimia untuk menentukan marker prognostik dilakukan berdasarkan stadium Enneking melalui analisis ekspresi $\beta 4$ integrin dan COX-2. Penelitian yang ada tentang perbedaan ekspresi antara $\beta 4$ integrin dan COX-2 terhadap stadium Enneking osteosarkoma masih belum banyak digali secara mendalam. Padahal pada beberapa penelitian menyebutkan ekspresi $\beta 4$ integrin dan COX2 yang meningkat dilaporkan pada osteosarkoma derajat tinggi, sehingga diperlukan suatu parameter prognostik dengan pemeriksaan imunohistokimia sehingga tata laksana terapi dilakukan lebih komprehensif dan pada akhirnya dapat meningkatkan ketahanan hidup penderita.

Penelitian ini bertujuan untuk mengetahui ekspresi $\beta 4$ integrin dan COX-2 sebagai marker prognostik pada osteosarkoma stadium Enneking IIB dan IIIB sebagai stadium terbanyak pasien yang datang ke RSUD Dr. Soetomo. 


\section{Bahan dan Metode}

\section{Rancangan dan Sampel Penelitian}

Rancangan penelitian yang digunakan adalah analitik observasional dengan pendekatan cross sectional karena observasi dilakukan pada variabel dengan kejadian sudah terjadi dari pengamatan sesaat dan tanpa intervensi pada objek penelitian.

Sampel penelitian dengan teknik pengambilan sampel total sampling berdasarkan kriteria inklusi yaitu: A). Hasil pemeriksaan histopatologik periode 1 Januari 2013-31 Desember 2017 ditegakkan oleh dokter spesialis patologi anatomi RSUD Dr. Soetomo Surabaya dengan hasil sesuai osteosarkoma, B). Didapatkan hasil radiologi dari foto polos lokasi tumor dan thorax atau pemeriksaan CT scan atau MRI, C). Dicantumkan stadium Enneking pada diagnosis osteosarkoma, blok D). Parafin masih memiliki sel tumor yang cukup representatif untuk dilakukan pemeriksaan imunohistokimia. Berdasarkan kriteria tersebut didapatkan 39 blok parafin penderita osteosarkoma stadium Enneking IIB dan IIIB di RSUD Dr. Soetomo Surabaya, masingmasing terdiri dari 18 sampel dan 21 sampel.

\section{Pulasan dan Analisis Hasil Imunohistokimia}

Sampel dipulas dengan pengecatan imununohistokimia (IHK) menggunakan antibodi monoklonal $\beta 4$ integrin (sc-514426, Santa Cruz Biotechnology, Inc., Oregon, USA) dengan pengenceran 1/150 dan COX-2 (RMA-B006, Diagnostic biosystem, CA, USA) dengan pengenceran $1 / 75$, ekspresi dinilai berdasarkan nilai scoring semikuantitaif. Kontrol $\beta 4$ integrin digunakan blok parafin dari mixed invasive carsinoma mammae of no special type grade II dan invasive lobular carsinoma yang terpulas positif pada sitoplasma sel tumor. Kontrol COX-2 adalah blok parafin dari adenokarsinoma colon yang terpulas positif pada sitoplasma sel tumor. Blok parafin dipotong dengan ketebalan $3 \mu \mathrm{m}$ dengan mikrotom, ditempatkan pada slide mikroskopis dilapisi dengan poli-L-lisin dan dipulas dengan antibodi $\beta 4$ integrin dan COX2, counterstain dengan hematoxylin mayer selama 5 menit, slide dicelupkan ke dalam alkohol bertingkat $70 \%, 96 \%$, dan $100 \%$, masing selama 5 menit kemudian xylol 1 dan xylol 2 masing-masing selama 10 menit. Jaringan diperiksa menggunakan mikroskop cahaya intensitas lemah-kuat dengan penentuan skor sebagai berikut: Skor $0=$ negatif/tidak terpulas. Skor $+1=$ terpulas pada sitoplasma sel tumor $\leq 10 \%$. Skor $+2=$ terpulas pada sitoplasma sel tumor $>10 \%$ hingga $\leq 50 \%$. Skor $+3=$ terpulas pada sitoplasma sel tumor $>50 \%$. Penentuan skor ekspresi COX-2 adalah: Skor $0=$ negatif/tidak terpulas. Skor $+1=$ intensitas sangat lemah, terpulas pada sitoplasma sel tumor $\leq 10 \%$. Skor $+2=$ intensitas lemah-sedang, terpulas pada sitoplasma sel tumor $>10 \%$ hingga $<30 \%$. Skor $+3=$ intensitas sedang, terpulas pada sitoplasma sel tumor $30 \%$ hingga $<50 \%$. Skor $+4=$ intensitas kuat, terpulas pada sitoplasma sel tumor $>50 \% .{ }^{18}$

\section{Analisis Statistik}

Perbedaan ekspresi $\beta 4$ integrin dan COX-2 dianalisis dengan uji statistik Mann Whitney sedangkan hubungan antar variabel dianalisis menggunakan tes korelasi Spearman.

\section{Hasil}

\section{Ekspresi $\beta 4$ Integrin}

Pada Gambar 1 ditunjukkan ekspresi $\beta 4$ integrin pada osteosarkoma. Berdasarkan Tabel 1 pada osteosarkoma stadium Enneking IIB didapatkan hasil terbanyak pada skor 3 yaitu 8 sampel $(20,51 \%)$, serupa pada stadium Enneking IIIB pada skor 3 yaitu 9 sampel $(23,07 \%)$. Hasil uji Mann Whitney menunjukkan $p=0,195$ artinya tidak ada perbedaan ekspresi $\beta 4$ integrin antara 
osteosarkoma stadium Enneking IIB dan IIIB ( $p$ $>0,05)$ (Tabel 2).

Tabel 1. Ekspresi $\beta 4$ integrin pada osteosarkoma stadium Enneking IIB dan IIIB.

\begin{tabular}{cccc}
\hline Skor & Stadium Enneking IIB & Stadium Enneking IIIB & Total \\
\hline 1 & $6(15,3 \%)$ & $1(2,56 \%)$ & $7(17,94 \%)$ \\
2 & $7(17,94 \%)$ & $8(20,51 \%)$ & $15(38,46 \%)$ \\
3 & $8(20,51 \%)$ & $9(23,07 \%)$ & $17(43,58 \%)$ \\
\hline Total & $21(53,8 \%)$ & $18(46,1 \%)$ & $39(100 \%)$ \\
\hline
\end{tabular}
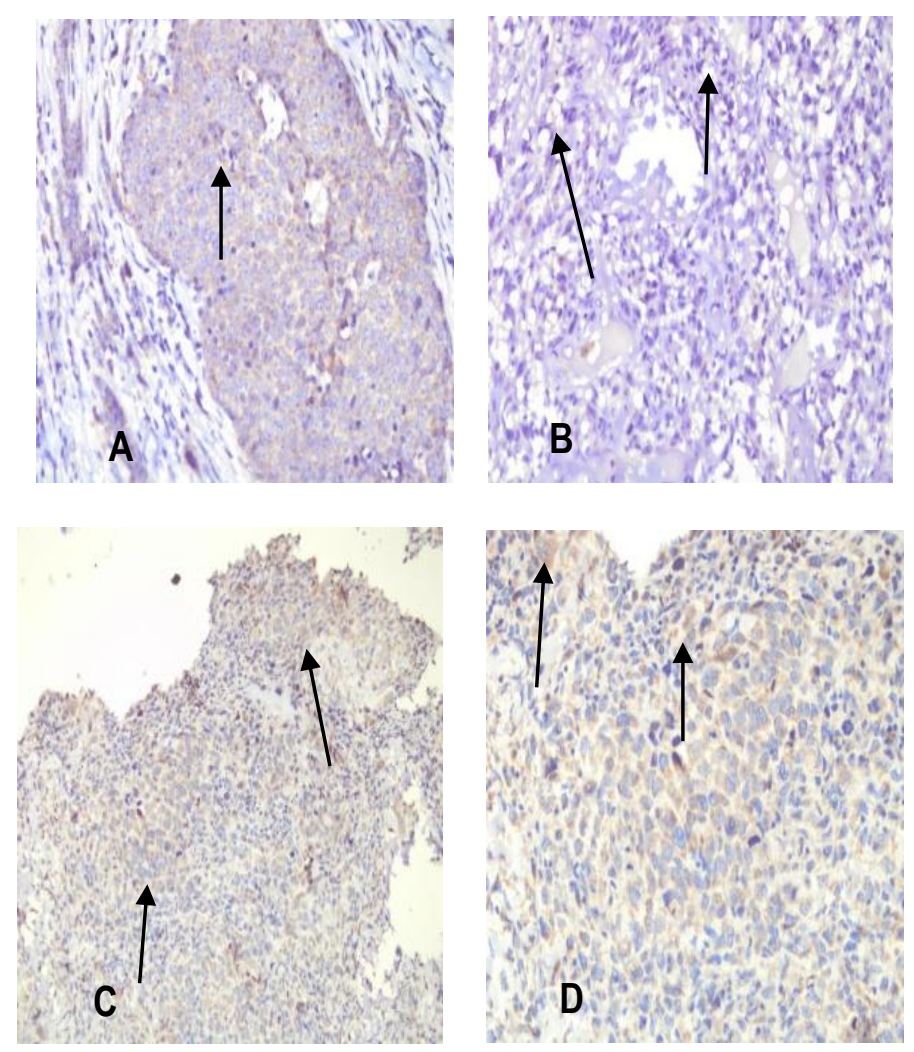

Gambar 1. Ekspresi $\beta 4$ integrin pada osteosarkoma dengan pengecatan IHK (tanda panah hitam). Keterangan: A. kontrol, B. Skor 1, C. Skor 2, D.Skor 3. (400 x).

Tabel 2. Uji statistik Mann Whitney $\beta 4$ integrin.

\begin{tabular}{ccccccc}
\hline & Minimum & $25 \%$ & Median & $75 \%$ & Maximum & Nilai $p$ \\
\hline StadiumEnneking IIB & 1 & 1 & 2,0 & 3 & 3 & 0,195 \\
Stadium Enneking.IIIB & 1 & 2 & 2,5 & 3 & 3 & \\
\hline
\end{tabular}


Tabel 3. Uji Spearman ekspresi $\beta 4$ integrin.

\begin{tabular}{|c|c|c|c|c|}
\hline & & & Std.Enneking IIB & Std.Enneking IIIB \\
\hline \multirow{6}{*}{ Spearman's rho } & Std.Enneking IIB & Correlation Coefficient & 1.000 & .268 \\
\hline & & Sig. (2-tailed) & & .282 \\
\hline & & N & 18 & 18 \\
\hline & Std.Enneking IIIB & Correlation Coefficient & .268 & 1.000 \\
\hline & & Sig. (2-tailed) & .282 & \\
\hline & & $N$ & 18 & 18 \\
\hline
\end{tabular}

Pada penelitian ini hasil uji Spearman menunjukkan adanya koefisien korelasi 0,268 dengan $p=0,282(p>0,05)$ yang artinya tidak ada hubungan ekspresi $\beta 4$ integrin antara stadium Enneking IIB dan IIIB.

\section{Ekspresi COX-2}

Berdasarkan Tabel 4 pada osteosarkoma stadium Enneking IIB didapatkan hasil terbanyak pada skor 4 yaitu 10 sampel $(25,64 \%)$, sedangkan pada stadium Enneking IIIB juga pada skor 4 yaitu 8 sampel (20,51\%). Hasil analisis berdasarkan Tabel 5 menunjukkan $p=0,868$ artinya tidak ada perbedaan ekspresi COX-2 antara osteosarkoma stadium Enneking IIB dan IIIB ( $p$ $>0,05)$. Pada penelitian ini menunjukkan adanya koefisien korelasi 0,054 dengan $p=$ $0,831(p>0,05)$ artinya tidak ada hubungan ekspresi $\beta 4$ integrin antara stadium Enneking IIB dan IIIB.

Hubungan Ekspresi $\beta 4$ Integrin dengan COX-2 pada Osteosarkoma Stadium Enneking IIB dan IIIB

Hubungan antara ekspresi $\beta 4$ Integrin dengan COX-2 pada osteosarkoma stadium Enneking IIB dan IIIB dilakukan uji statistik dengan uji korelasi Spearman. Didapatkan $p=$ $0,008(a<0,05)$, menunjukkan ada korelasi yang signifikan antara ekspresi $\beta 4$ integrin dengan COX-2 pada osteosarkoma stadium Enneking IIB dan IIIB dengan koefisien korelasi 0,41 .

Tabel 4. Ekspresi COX-2 pada osteosarkoma stadium Enneking IIB dan IIIB.

\begin{tabular}{cccc}
\hline Skor & Stadium Enneking IIB & Stadium Enneking IIIB & Total \\
\hline 1 & $2(5,12 \%)$ & $1(2,56 \%)$ & $3(7,69 \%)$ \\
2 & $2(5,12 \%)$ & $3(7,69 \%)$ & $5(12,82 \%)$ \\
3 & $7(17,94 \%)$ & $6(15,38 \%)$ & $13(33,33 \%)$ \\
4 & $10(25,64 \%)$ & $8(20,51 \%)$ & $18(46,15 \%)$ \\
Total & $21(53,84 \%)$ & $18(46,15 \%)$ & $39(100 \%)$ \\
\hline
\end{tabular}



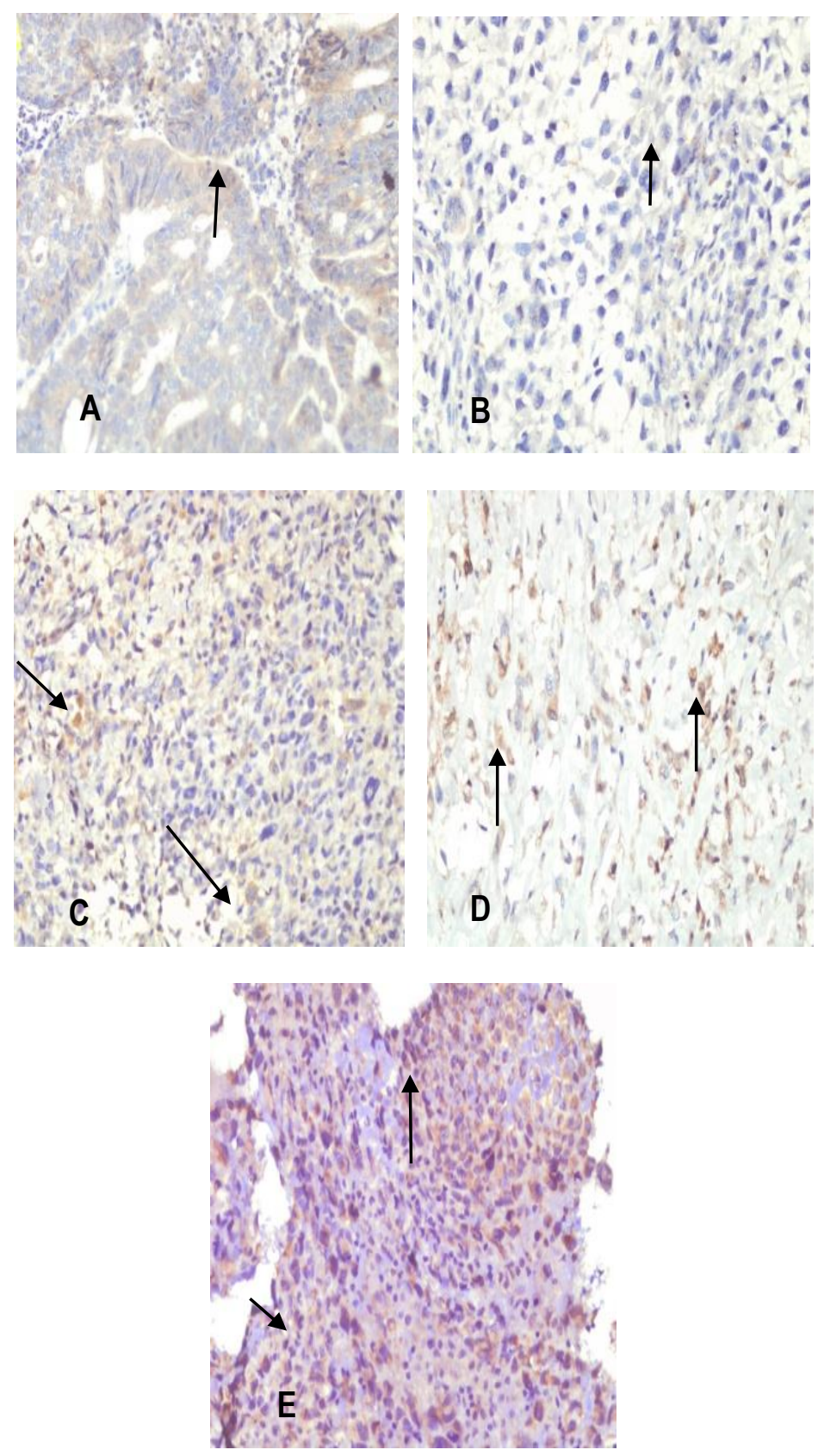

Gambar 1. Ekspresi COX-2 pada osteosarkoma dengan pengecatan IHK (tanda panah hitam). Keterangan: A.Kontrol, B. Skor 1, C. Skor 2, D.Skor 3, E. Skor 4 (400 x).

Tabel 5. Uji statistik Mann Whitney COX-2.

\begin{tabular}{ccccccc}
\hline & Minimum & $25 \%$ & Median & $75 \%$ & Maximum & Nilai $p$ \\
\hline Std.Enn IIB & 1 & 3 & 3 & 4 & 4 & 0,868 \\
Std.Enn.IIIB & 1 & 3 & 3 & 4 & 4 & \\
& & & & & & \\
\hline
\end{tabular}


Tabel 6. Uji Spearman ekspresi COX-2.

\begin{tabular}{lclcc}
\hline & & Std.Enneking IIB & Std.Enneking IIIB \\
\hline Spearman's rho & Std.Enn.IIB & Correlation & 1.000 & .054 \\
& & Coefficient & & \\
& Sig. (2-tailed) &. & .831 \\
& $N$ & 21 & 18 \\
& \multirow{3}{*}{ Std.Enn.IIIB } & Correlation & .054 & 1.000 \\
& & Coefficient & & \\
& Sig. (2-tailed) & .831 &. \\
& $N$ & 18 & 18 \\
\hline
\end{tabular}

\section{Pembahasan}

Ekspresi $\beta 4$ Integrin pada Osteosarkoma Stadium Enneking IIB dan IIIB

$\beta 4$ integrin dapat terekspresi pada sitoplasma sel tumor. ${ }^{7}$ Pada penelitian ini tidak didapatkan perbedaan ekspresi $\beta 4$ integrin pada stadium Enneking IIB dan IIIB. Hasil penelitian ini menunjukkan ekspresi $\beta 4$ integrin tidak dapat digunakan sebagai marker prognosis pada stadium Enneking IIB dan IIIB. Stadium IIB dan IIIB secara morfologi berada pada kategori derajat diferensiasi tinggi, mitosis mudah didapatkan, rasio jumlah sel lebih tinggi dibandingkan matriks. Stadium III ditandai adanya metastasis (kelenjar getah bening atau metastasis jauh) dengan sel-sel tumor derajat diferensiasi tinggi. ${ }^{8}$

Ekspresi $\beta 4$ integrin tidak menunjukkan perbedaan pada stadium Enneking IIB dan IIIB. Hal ini karena pada sel tumor dengan derajat diferensiasi yang tinggi dapat memicu pelepasan $\beta 4$ integrin dari hemidesmosom sehingga terjadi perubahan sinyal-sinyal yang memicu pertumbuhan sel, invasi sel, dan metastasis. Ikatan $\beta 4$ integrin pada laminin secara langsung mengaktifkan jalur $\mathrm{PI} 3 \mathrm{~K}$ dan RhoA small GTPases. Selain itu, $\beta 4$ integrin juga bekerja sama dengan banyak faktor pertumbuhan seperti reseptor famili EGF (ErbB-1,2,3), c-Met, LPA1, LPA2 dan Ron untuk menguatkan sinyal melalui jalur PI3K, AKT, MAPK, dan RhoA small GTPases. ${ }^{5}$
Satu mekanisme untuk aktivasi integrin $\beta 4$ yang dimediasi PI3K melibatkan substrat reseptor insulin-1 dan -2 (IRS-1 dan IRS-2) yang bertindak sebagai sinyal intermediet untuk aktivasi PI3K a6ß4. Ligasi integrin a6ß4 meningkatkan fosforilasi IRS-1 dan IRS-2, yang mengarah ke aktivasi berikutnya dari PI3K. a6ß34 bekerja sama dengan ErbB-2 untuk mempromosikan PI3K. Integrin a6ß4 mengaktifkan $\mathrm{PI} 3 \mathrm{~K}$ dengan memfasilitasi interaksi tirosin kinase. Keterlibatan integrin a6ß4 dalam polarisasi sel dan pembentukan struktur motilitas F-actin seperti filopodia dan lamellae mengarah ke Rho small GTPases yang mengontrol reorganisasi sitoskeleton aktin untuk motilitas sel. Penelitian awal oleh Shaw dkk. pada aktivasi dan fungsi PI3K dalam invasi menemukan bahwa GTPase Rac1 diperlukan untuk invasi hilir PI3K. ${ }^{9}$ Studi lebih lanjut yang meneliti dampak integrin a6ß4 pada migrasi dan invasi menemukan bahwa integrin a6 $\beta 4$ dapat meningkatkan aktivitas phosphodiesterase spesifik CAMP sehingga menurunkan konsentrasi cAMP dan aktivasi RhoA. Aktivasi RhoA oleh integrin a6ß4 mengarah ke pembentukan ruffling membran RhoAdependent dan pembentukan lamellae, migrasi sel. Stewart dkk. menemukan bahwa metastasis terkait protein $\mathrm{S} 100$ yang diatur oleh integrin a6 $\beta 4$ berinteraksi dengan Rho effector Rhotekin mempromosikan membran sel ruffling integrin a6 $\beta 4$ dapat merubah fungsi RhoA untuk memfasilitasi invasi 
tumor..$^{5}$ Integrin a6ß4 menguatkan sinyal melalui beberapa reseptor tirosin kinase dan reseptor berpasangan $G$ protein untuk mengaktifasi proliferasi sel tumor dan invasi. EGFR dan integrin a6ß4 juga telah terbukti menyebabkan colocalize pada sel karsinoma yang mengalami stimulasi EGF. ${ }^{5}$

Pada penelitian sebelumnya yang dilakukan oleh Xiaolin dkk terhadap osteosarkoma derajat tinggi dan rendah didapatkan perbedaan ekspresi $\beta 4$ integrin yang terpulas positif kuat pada semua sampel osteosarkoma derajat dan stadium tinggi, sedangkan pada derajat dan stadium rendah terpulas positif lemah, tidak didapatkan pulasan yang negatif. Pada penelitian tersebut juga dilaporkan bahwa pada osteosarkoma derajat tinggi berhubungan dengan ekspresi $\beta 4$ integrin yang berlebihan, hasil sebaliknya terjadi pada derajat rendah. ${ }^{7}$

Pemeriksaan dengan metode imunohistokimia oleh Li dkk. pada 82 penderita hepatocellular carcinoma (HCC) baik yang metastasis maupun belum metastasis, serta pada jaringan hepar tanpa kelainan tertentu mendapatkan ekspresi $\beta 4$ integrin berlebihan pada HCC dengan metastasis dan ekspresi kuat didapatkan pada tumor di tempat metastasis. Penelitian tersebut juga mendapatkan hubungan yang signifikan $(p<0,01)$ antara ekspresi $\beta 4$ integrin berlebihan dengan derajat histopatologik dan stadium dari HCC. ${ }^{10}$

Penelitian oleh Nagata dkk. terhadap 270 penderita squamous cell carcinoma (SCC) pada organ mulut dengan antibodi $\beta 4$ integrin, a3 integrin, CD9 dan plakoglobin (JUP) dengan Real Time Polymerase Chain Reaction (RT-PCR) mendapatkan bahwa rasio $\beta 4$ integrin terhadap JUP yang tinggi terjadi pada kasus dengan metastasis jauh ( $p$ $=0,003$ ). Penelitian ini lebih banyak mengkaji pendekatan kuantitatif untuk mendapatkan biomarker prognostik dari SCC pada rongga mulut. ${ }^{11}$ Gleason dkk. dalam penelitian yang dilakukan terhadap adenokarsinoma pankreas juga melaporkan bahwa ekspresi berlebihan terjadi pada 44 kasus adenokarsinoma di antara 48 kasus (92\%) dibandingkan dengan kasus pankreatitis kronik dan pankreas normal. ${ }^{12}$

Pada beberapa penelitian dengan sampel yang didapat dari penderita osteosarkoma yang menjalani kemoterapi neoadjuvant secara inheren terbatas dalam ukuran sehingga rentan terhadap kesalahan sampling dan kurang mencerminkan keseluruhan tumor secara akurat. Selain itu, perilaku agresif tumor yang dicerminkan dalam tingkat mitosis, LVI (lymp-vascular invasi), pleomorfisme inti ditemukan secara signifikan berkorelasi dengan kelangsungan hidup di praperlakuan. Penelitian oleh Bacchi dkk. menyatakan meluasnya penggunaan kemoterapi neoadjuvant dalam pengobatan osteosarkoma, nekrosis tumor spontan ditemukan menjadi faktor prognostik independen, bahkan setelah disesuaikan dengan ukuran tumor ada hubungan yang lebih kuat yang mungkin disebabkan oleh perkiraan nekrosis yang lebih akurat pada pemeriksaan reseksi bedah daripada biopsi. Ukuran tumor, lokasi anatomi dan status metastasis pada presentasi adalah penentu kuat dari hasil bertahan hidup. ${ }^{13}$ Lazimnya, respons terhadap kemoterapi dijelaskan dalam istilah nekrosis tumor, mirip dengan peneliti lain, namun pada penelitian ini cenderung menggunakan istilah berdasarkan persen sel tumor yang layak. Perbedaan seperti itu meliputi tumor nekrosis, adanya fibrosis dan matriks aseluler sebagai unsurunsur tumor yang tidak dapat bertahan, dan secara kumulatif mewakili efek pengobatan. ${ }^{14}$

Pada penelitian Bottini dkk. menunjukkan bahwa pengaruh kemoterapi menyebabkan perubahan ukuran dan jumlah sel menjadi lebih kecil serta mempengaruhi jumlah sel yang berada pada siklus sel, akan tetapi pengaruh kemoterapi primer menyebabkan perubahan minimal pada agresifitas dan biologi tumor. ${ }^{15}$ 
Ekspresi COX-2 pada Osteosarkoma Stadium Enneking IIB dan IIIB

Ekspresi COX-2 dinilai secara semikuantitatif dengan menilai pulasan pada sitoplasma sel tumor dalam bentuk persentase dan diklasifikasikan dalam bentuk scoring, kemudian dilakukan uji normalitas pada seluruh variabel dan uji beda dengan Mann Whitney. Hasil uji normalitas pada penelitian ini mendapatkan hasil ekspresi COX-2 pada stadium Enneking IIB dan IIIB tidak berdistribusi normal. Selanjutnya tidak didapatkan perbedaan bermakna ekspresi COX-2 pada stadium Enneking IIB dan IIIB dengan $p=0,87(p>0,05)$.

Stadium Enneking IIB dan IIIB dikategorikan pada derajat diferensiasi tinggi, perbedaan terletak pada adanya metastasis. Ekspresi COX-2 yang berlebihan didapatkan pada sel-sel tumor dengan derajat diferensiasi tinggi dan pada tumor di tempat metastasis. Hal yang mendasari adalah ekspresi konstitutif COX-2 dan biogenesis berkelanjutan PGE2 berperan utama dalam inisiasi dan promosi perkembangan kanker. PGE2 yang menjadi perantara efek ini melalui banyak jalur sinyal termasuk aktivasi faktor pertumbuhan endotel vaskular (VEGF) yang menyebabkan peningkatan proliferasi sel, metastasis dan invasif potensial, dan angiogenesis Ekspresi yang meningkat dari proto-onkogen, BCL-2, dan EGFR, melalui aktivasi mitogenaktivatedprotein kinase (MAPK) dan fosfoinositida3-kinase (PI3K) atau jalur AKT, masing-masing jalur dapat meningkatkan aktifitas transkripsi dari mediator antiapoptosis nuclear factor $\mathrm{KB}$ (NFkB), peningkatan metastasis dan invasi dengan aktivasi matriks metaloprotease (MMP-2 dan MMP-9) dan penekanan produksi IL-12 menyebabkan imunosupresi. Selain itu, PGE2 yang diaktivasi oleh COX-2 akan mengaktifkan jalur-jalur yang terkait dengan survival sel-sel dan proliferasi. COX-2 juga bekerjasama dengan marker CSC yang lain seperti CD44, CD133, Oct3/4, LGR5,
SOX-2, ALDH. Marker CSC tersebut memiliki kemampuan untuk menumbuhkan kolonikoloni spheroid yang mendorong proliferasi sel-sel undifferentiated. Stadium IIB dan IIIB memiliki derajat diferensiasi tinggi pada sel tumor sehingga tidak didapatkan perbedaan ekspresi COX-2 maupun keterkaitan. ${ }^{6}$

Hasil penelitian ini berbeda dengan penelitian yang dilakukan oleh Fang dkk. tentang ekspresi COX-2 dan micro-RNA pada osteosarkoma. Sebanyak 26 sampel osteosarkoma dari RS Jingling diambil dari periode desember 2011 hingga desember 2013 dan didapatkan 9 sampel dengan stadium I, 8 sampel stadium II dan 3 sampel stadium III. Didapatkan ekspresi yang berlebihan pada stadium II dibanding stadium l. ${ }^{16}$

Penelitian yang dilakukan oleh Urakawa dkk. terhadap 51 pasien osteosarkoma tipe konvensional pada ekstremitas yang belum menjalani kemoterapi mendapatkan hasil yang berbeda dengan penelitian ini. Pada penelitian tersebut didapatkan perbedaan ekspresi pada osteosarkoma derajat tinggi dengan $p=0,029.17$ Sejalan dengan penelitian yang dilakukan oleh Dickens dkk. yang mendapatkan ekspresi berlebihan pada sarkoma yang metastasis dibandingkan pada nonmetastasis yaitu pada osteosarkoma, rhabdomyosarkoma dan Ewing sarkoma. 18,19

Pada penelitian ini tidak didapatkan hubungan antara ekspresi COX-2 dengan stadium Enneking IIB dan IIIB osteosarkoma. Hasil tersebut sejalan dengan penelitian Urakawa dkk. terhadap 51 penderita osteosarkoma yang sudah mendapatkan neoadjuvant kemoterapi menyebutkan tidak didapatkan hubungan antara ekspresi COX-2 pada osteosarkoma derajat tinggi stadium AJCC IIA, IIB dan IIIB. ${ }^{17}$ Penelitian oleh Rodriguez dkk. melaporkan pada 36 penderita osteosarkoma yang disertai metastasis maupun tanpa metastasis tidak didapatkan hubungan ekspresi COX-2. Pada penelitian tersebut didapat $p=0,325(p>$ 
0,05). Faktor metastasis tumor, perluasan area nekrosis, lokasi primer dari tumor, jenis histopatologik juga diteliti walaupun mendapatkan hasil yang tidak berhubungan. ${ }^{19}$

Uraian sebelumnya telah jelas menjabarkan bahwa pada stadium Enneking IIB dan IIIB yang berada pada kategori derajat diferensiasi tinggi tidak didapatkan hubungan dengan ekspresi COX-2 karena memiliki pola aktifitas dan pengaruh yang sama serta melibatkan berbagai jalur sinyal yang saling mempengaruhi satu sama lain.

Hubungan Ekspresi $\beta 4$ Integrin dan COX-2 pada Osteosarkoma Stadium Enneking IIB dan IIIB

Hubungan antara ekspresi $\beta 4$ integrin dengan COX-2 pada osteosarkoma stadium Enneking IIB dan IIIB diuji statistik dengan uji korelasi Spearman. Didapatkan hasil $p=$ $0,008(p<0,05)$ dengan koefisien korelasi 0,41 . Hal ini membuktikan adanya hubungan antara ekspresi $\beta 4$ integrin dan COX-2 pada osteosarkoma stadium Enneking IIB dan IIIB, yang berarti semakin tinggi ekspresi $\beta 4$ integrin semakin tinggi pula ekspresi COX-2.

Selama ini belum pernah ada penelitian yang menganalisis hubungan antara ekspresi $\beta 4$ integrin dan COX-2 pada osteosarkoma berdasarkan stadium Enneking. Penelitan yang dilakukan oleh Song dkk. tentang mekanisme IncRNA pada sel kanker lambung dengan terapi celecoxib (COX-2 inhibitor) yang melibatkan berbagai jaringan protein, melaporkan adanya upregulation dan downregulation dari jalur-jalur sinyal yang terlibat di dalamnya salah satunya adalah $\beta 4$ integrin yang menyebabkan terhambatnya sel-sel kanker lambung. Penelitian tersebut menggunakan sejumlah 490 DEGs (Differentially Expressed Gene). ${ }^{20}$

Ekspresi $\beta 4$ integrin dan COX-2 memiliki keterkaitan yang signifikan. Integrin sebagai protein transmembran yang berada di perbatasan plasma membran mempengaruhi jalur-jalur yang ada di bawahnya antara lain
FAK, ILK, IRK, PI3K, NFkB. ${ }^{21}$ Berbeda dengan subunit $\beta$ lainnya, $\beta 4$ integrin mengandung domain $\beta 4$ sitoplasmik unik (1017 asam amino). Domain ini tidak berbagi homologi dengan subunit $\beta$ lain, dan memiliki fungsi cytoskeletal dan signaling yang berbeda. ${ }^{22}$ Residu tirosin spesifik dalam domain sitoplasma integrin $\beta 4, Y 1494$ telah diidentifikasi dan diperlukan untuk aktivasi PI3K. ${ }^{9}$ Ekspresi integrin $\beta 4$ dipertahankan, atau sering diregulasi, dalam berbagai jenis tumor invasif dan metastatik. Tingginya kadar integrin ini telah dikaitkan dengan prognosis buruk pada jenis tumor ini. ${ }^{23} \beta 4$ integrin juga bekerja sama dengan beberapa reseptor onkogenik tirosin kinase (RTKs), seperti EGF$R$, ErbB2 / Neu dan Met, dan meningkatkan kelangsungan hidup sel, proliferasi, invasi dan migrasi. ${ }^{24,25,26}$

Sejumlah penelitian telah menunjukkan bahwa ekspresi dan fungsi $\beta 4$ integrin terlibat dalam perkembangan kanker. ${ }^{23,24,25,27}$ Data ini memberikan bukti bahwa ekspresi berlebihan $\beta 4$ integrin meningkatkan metastasis tumor dan menunjukkan bahwa blokade $\beta 4$ integrin secara rasional dapat menghambat metastasis tumor pada pasien dengan osteosarkoma. ${ }^{28}$

Dalam penelitian yang dilakukan oleh Qu dkk. melaporkan bahwa Celecoxib, penghambat siklooksigenase-2, menginduksi apoptosis pada manusia melalui garis sel osteosarcoma MG-63 dengan mengatur downregulation dari PI3K/Akt. ${ }^{28}$ PI3K/Akt memainkan peran penting dalam sel/Extra Cellular Matrix (ECM) dan adhesi sel-sel. ${ }^{28}$ Peran tersebut juga dimiliki oleh $\beta 4$ integrin. Kurangnya adhesi yang benar akan mendorong terjadinya apoptosis terkait adhesi (anoikis). Aktivasi sinyal PI3K/Akt telah terbukti memediasi sinyal kelangsungan hidup yang dipicu oleh keterlibatan Ecadherin dan cadherin klasik lainnya. Penghubung yang memungkinkan antara integrin dan $\beta$-catenin adalah integrin aktif, antiapoptotic kinase PKB/Akt. PKB dikenal 
untuk menghambat aktivitas glikogen sintase kinase 3- $\beta$ yaitu serin kinase yang berfungsi langsung untuk mengurangi protein $\beta$ catenin dan memberi sinyal. Adanya faktor neurotropik yang diturunkan dari otak (BDNF) yang berikatan dengan reseptor TrkB menghasilkan reseptor yang sangat spesifik autofosforilasi dan pada gilirannya mengaktifkan PI3K dan jalur Akt. Target lain dari jalur PI3K/Akt bisa jadi survivin. Survivin adalah anggota dari penghambat protein apoptosis (IAP).$^{28}$ Kesimpulan pada penelitian ini didapatkan hubungan bermakna dengan koefisien korelasi $>0,40$ antara $\beta 4$ integrin dan COX-2, sehingga ekspresi $\beta 4$ integrin yang meningkat juga menyebabkan peningkatan ekspresi COX-2.

\section{Kesimpulan}

Tidak didapatkan hubungan antara $\beta 4$ integrin dan COX-2 pada osteosarcoma stadium Enneking IIB dan IIIB yang menunjukkan bahwa kedua antibodi itu tidak dapat digunakan sebagai marker prognostik pada stadium tersebut.

\section{Saran}

Penelitian lebih lanjut perlu dilakukan dengan sampel dari bahan operasi maupun biopsi pada penderita yang belum mendapatkan maupun telah mendapat kemoterapi pada semua stadium Enneking. Perlu penelitian lanjutan dengan biomarker lain yang ikut mempengaruhi ekspresi $\beta 4$ integrin dan COX-2 sehingga dapat digunakan sebagai marker prognostik, seperti osterix dan RUNX2 yang berperan pada osteogenesis, ezrin, MMP, CD44, subtipe a dan $\beta$ integrin yang lain.

\section{Daftar Pustaka}

1. Komite Penanggulangan Kanker Nasional. Pedoman Nasional Pelayanan
Kedokteran, Osteosarkoma. Kementerian kesehatan. 2010.

2. Fletcher $\mathrm{C}$, Bridge J. WHO Classification of tumors of Soft Tissue and Bone. $4^{\text {th }}$ Edition. Sanders Elsevier. 2013. P. 281295.

3. Samardziski M, Zanevska V, Gamokanin S,. Osteosarcoma: Diagnosis and Treatment. Journal of Pediatric Science. 2010; 2(e27).

4. Ata R and Antonescu CN. Integrins and Cell Metabolism : An Intimate Relationship Impacting Cancer. Int J Mol Sci. 2017; 18(1):E189. doi: 10.3390/ijms18010189

5. Stewart RL, Connor KLO. Pathobiology in Focus: Clinical Significance of the Integrin a6ß4 in Human Malignancies. Lab Invest. 2015; 95:976-86.

6. Pang LY, Hurst EA, Argyle DJ. Cyclooxygenase-2: A Role in Cancer Stem Cell Survival and Repopulation of Cancer Cells during Therapy. Stem Cell Int. 2016;2016:2048731.

7. Wan X, Kim SY, Guenther LM, Mendoza A, Briggs J, Yeung C, et al. HHS Public Access. 2010;28(38):3401-11.

8. Kundu ZS. Classification, Imaging, Biopsy and Staging of Osteosarcoma. Indian J Orthop. 2014; 48(3):238-246. doi: 10.4103/0019-5413.132491.

9. Shaw LM. Identification of Insulin Receptor Substrate (IRS-1) and IRS-2 as Signalling Intermediates in the $\alpha 6 \beta 4$ IntegrinDependent Activation of Phosphoinositide 3-OH Kinase and Promotion of Invasion. Mol Cell Biol. 2001; 21(15):5082-93.

10. Li X, Liu L, Li D, He Y, Guo L, Sun L, et al. Integrin $\beta 4$ Promotes Cell Invasion and Epithelial-Mesenchymal Transition Through The Modulation of Slug Expression in Hepatocellular Carcinoma. Sci Rep. 2017; 7:40464. doi: 10.1038/srep40464.

11. Nagata $M$, Noman $A A$, Suzuki $K$, Kurita $H$, Ohnishi M, Ohyama T, et al. ITGA3 and ITGB4 Expression Biomarkers Estimate 
the Risks of Locoregional and Hematogenous Dissemination of Oral Squamous Cell Carcinoma. BMC Cancer. 2013; 13:410. doi: 10.1186/1471-2407-13410.

12. Gleason B, Adley B, Rao MS, Diaz LK. Immunohistochemical Detection of the ${ }_{\mathrm{L}} 4$ Integrin Subunit in Pancreatic Adenocarcinoma. Semin Oncol. 2005;53(6):799-801.

13. Bacci $G$, Longhi A, Versari M, Mercuri $M$, Briccoli A, Picci P. Prognostic Factors for Osteosarcoma of the Extremity Treated with Neoadjuvant Chemotherapy: 15Year Experience in 789 Patients Treated at a Single Institution Cancer. American Cancer Society Wiley InterScience. 2006; 106(5):1154-1161. doi: 10.1002/cncr.21724.

14. Chui MH, Kandel RA, Wong M, Griffin $A M$, Bell RS, Blackstein $M E$, et al. Histopathologic Features of Prognostic Significance in High-Grade Osteosarcoma. Arch Pathol Lab Med. 2016; 140.

15. Bottini A, Berruti A, Bersiga A, Brizzi MP, Bruzzi $P$, Aguggini $S$, et al. Relationship between Tumour Shrinkage and Reduction in Ki67 Expression after Primary Chemotherapy in Human Breast Cancer. Br J Cancer. 2001; 85(8):11061112.

16. Fang $Y$, Zhang $Z$, Wang $Q$, Zhao J. Expression and Clinical Significance of Cyclooxygenase-2 and MicroRNA-143 in Osteosarcoma. Exp Ther Med. 2015; 9(6):2374-2378.

17. Urakawa $H$, Nishida $Y$, Naruse $T$, Nakashima $\mathrm{H}, \quad$ Ishiguro $\mathrm{N}$. Cyclooxygenase-2 Overexpression Predicts Poor Survival in Patients with High-grade Extremity Osteosarcoma. Clin Orthop Relat Res. 2009; 467(11):2932-8. doi: 10.1007/s11999-009-0814-x.

18. Dickens DS, Kozielski R, Khan PJ. Cyclooxygenase-2 Expression in Pediatric
Sarcomas. Pediatr Dev Pathol. 2002; 5:356-364.

19. Rodriguez NI, Hoots WK, Koshkina NV, Morales-Arias JA, Arndt CA. Inwards CY, Hawkins DS, Munsell MF, Kleinerman ES. COX-2 Expression Correlates with Survival in Patients with Osteosarcoma Lung Metastases. J Pediatr Hematol Oncol. 2008; 30(7): 507-512.

20. Song BIN, Du J, Feng YE, Gao YJ, Zhao JIS. Co-expressed Differentially Expressed Genes and Long Non-Coding RNAs Involved in the Celecoxib Treatment of Gastric Cancer: An RNA Sequencing Analysis. Experimental and Therapeutic Medicine. 2016; 12(4):2455-2468.

21. Ganguly KK, Pal S, Moulik S, Chatterjee A. Integrins and Metastasis. Cell Adhes Migr 2013; 7(3):251-61:251-61.

22. Giancotti FG, Ruoslahti E. Integrin Signaling. Science. 1999; 285:1028-32; PMID:10446041; $\quad$ http://dx.doi. org/10.1126/science.285.5430.1028.

23. Mercurio AM, Rabinovitz I, Shaw LM. The a6ß4 Integrin and Epithelial Cell Migration. Curr Opin Cell Biol. 2001; 13(5):541-5.

24. Mariotti A, Kedeshian PA, Dans $M$, Curatola AM, Gagnoux-Palacios L, Giancotti FG. EGF-R Signalling Through Fyn Kinase Disrupts the Function of Integrin a $6 \beta 4$ at Hemidesmosome. J Cell Biol. 2001; 155(3):447-58.

25. Guo W, Pylayeva Y, Pepe A, Yoshioka T, William JM, Inghirami G, Filippo GG. ß4 Integrin Amplifies ErbB2 Signalling to Promote Mammary Tumorigenesis. Cell. 2006; 126(3):489-502.

26. Trusolino L, Bertotti A, Comoglio PM. A Signalling Adapter Function for a 6 B4 Integrin in the Control of HGF-Dependent Invasive Growth. Cell. 2001; 107(5):643654.

27. Nikulopoulos SN, Blaikie $P$, Yoshioka $T$, Guo W, Giancotti FG. Integrin $\beta 4$ Signalling Promotes Tumor Angiogenesis. 
Cancer Cell. 2004; 6(5):471-83.

29.28. Qu L, Liu B. Cyclooxygeanse-2

Promotes Metastasis in Osteosarcoma.

Cancer Cell. 2015;2-5.

http://dx.doi.org/10.1186/s12935-015-

0220-2. 